\title{
KNOWLEDGE AS THE INTERVENING VARIABLE ON RELIGIOSITY VALUE OF ACCOUNTANT STUDENTS' SAVING INTEREST FOR ISLAMIC BANKING
}

\author{
Wahyuning Murniati ${ }^{1}$, Evita Purnaningrum ${ }^{2}$ \\ ${ }^{1}$ Departement of Accunting, STIE Widya Gama Lumajang, Lumajang, 67352, Indonesia \\ 2 Departement of Management, Universitas PGRI Adi Buana, Surabaya, Indonesia \\ E-mail address: wahyuning123@gmail.com
}

\section{A R T I C L E I N F O}

Date of entry:

7 August 2020

Revision Date:

10 September 2020

Date Received:

15 September 2020

JEL Code: D83, E21, Z12

\begin{abstract}
A B S T R A C T
The development of Islamic economics in banking practices in society develops innovatively. Various sharia banking products have become the people's choice in supporting their daily economic activities. The same thing also happened to students. The purpose of study is to analyze the religiosity effect of students' interest in saving for Islamic banking with knowledge as intervening variable. Multiple linear regression is an analytical technique used here, with hypothesis testing and path analysis to support its conclusions. The result of this study is that the level of religiosity significantly effects on students' interest in saving for Islamic banking with positive relationship. Likewise, knowledge is able mediate the relationship between the religiosity variable and students' interest in saving.
\end{abstract}

Keywords: Knowledge, Saving Interest, Religiosity

Cite this as: Murniati, W., Purnaningrum, E. (2020). KNOWLEDGE AS THE INTERVENING VARIABLE ON RELIGIOSITY VALUE OF ACCOUNTANT STUDENTS' SAVING INTEREST FOR ISLAMIC BANKING. International Journal of Accounting and Management Research, 1(2), 63-68. https://doi.org/ 10.30741/ijamr.v1i2.645

\section{INTRODUCTION}

Islamic finance built on basis of the Islamic philosophy on the principle of justice. Therefore, financial practices based on Islamic economics must be far from usury. Riba is the excess that is collected along which contains elements of persecution and oppression. Riba is known as a term that is closely related to economic activity. The prohibition of usury is one of the main pillars of Islamic economics, in addition to the implementation of zakat and the prohibition of maisir, gharar and other things that are vanity (Murniati, 2018).

The concept of finance based on Islamic law has grown into a trend in the world economy, including in Indonesia. Based on sharia banking data, the growth of conventional banks is smaller than Islamic banks where Islamic banks have experienced relative growth of around $40 \%$ per year in the last ten years while conventional banks are $20 \%$ in Indonesia. (Direktorat Perbankan Syariah, 2011). Over time, the growth of Islamic banking exceeds conventional baking system for sure. Based on the Indonesian Sharia Financial Development Roadmap (Otoritas Jasa Keuangan, 2018), Islamic finance increase number of products and services, to supports Islamic finance. Even in the global market, Indonesia is among the top ten countries that have the largest Islamic financial index. However, the growth of Islamic finance has not been able to keep up with conventional 
financial growth. This can be seen from the market share (market share) of Islamic finance, which as a whole is still below 5\%. However, when viewed from each type of sharia product, until the end of December 2016, there were several sharia products with a market share of above 5\%, including Islamic banking assets of $5.33 \%$ of all banking assets, state sukuk which reached 14.82 . \% of total state securities in circulation, Islamic finance institutions of $7.24 \%$ of total financing, specialized Islamic financial services institutions of $9.93 \%$, and Islamic microfinance institutions of $22.26 \%$. Meanwhile, sharia products whose market share is still below $5 \%$ include corporate sukuk in circulation of $3.99 \%$ of the total value of sukuk and corporate bonds, and net asset value of Islamic mutual funds of $4.40 \%$ of the total net asset value of mutual funds. funds, and sharia insurance by $3.44 \%$. Apart from the aforementioned financial products, shares of issuers and public companies that meet the criteria as sharia shares account for $55.13 \%$ of the stock market capitalization listed on the Indonesia Stock Exchange. The figures above show that Indonesian Islamic finance still needs to be developed so that it can keep up with conventional financial growth in order to expand the financial industry as a whole.

Banking is related to the bank. The main function of Indonesian banking is as a collector and channel of public funds and aims to support the implementation of national development in order to increase equitable development and its results, economic growth and national stability, towards improving the standard of living of the people at large (Mujaddid, 2019; Otoritas Jasa Keuangan, 2016). Indonesia itself, which is a developing country, has a very fast banking development. This can be seen both in bank office facilities and in all banking products offered to the public, conventional and Islamic. Islamic banks are financial institutions that carry out an intermediary function (intermediary) in collecting public funds and channeling financing to the public in accordance with sharia principles (Mujaddid, 2019). This makes various Islamic banking products run based on a system that is far from usury. This is one of the things that affects the increasing interest in the use of Islamic banking products in the community, as well as among students.

STIE Widya Gama Lumajang is a tertiary institution located in Lumajang Regency. Along with the development of the concept of sharia in the economic sector, STIE Widya Gama Lumajang made several curriculum adjustments by adding several courses that were in accordance with the concept of sharia economics. Therefore, this study conducts to determine the effect of student religiosity on saving interest in Islamic banking with knowledge as an intervening variable. These variables are considered to be the most basic factors in determining saving interest for Islamic banking. Furthermore, the results obtained are expected to make a positive contribution to the development of studies on Islamic investment and provide readers with a deeper picture of Islamic investment. In addition, the results of this study are expected to reduce community involvement in the practice of usury and increase the development of Islamic economics in Indonesia

There are several related studies used in this study, among others; (Rahmawati, 2019) stated that based on the results of the first $t$ test, it was found that the variables of religiosity, trust and location had a positive and significant effect on people's interest in saving in Islamic banks, the promotional variable had a positive but not significant effect on the interest in saving. The results of the second $t$ test show that promotion, religiosity, trust, and location have a positive and significant effect on public knowledge of Islamic banks. The knowledge variable is able to mediate promotion, religiosity, trust and location on interest in saving in Islamic banks

Mujaddid (2019) entitled The Influence of Knowledge, Reputation, Environment and Religiosity on the Interests of Vocational High School Students in the Islamic Banking Study Program in Saving at Islamic Banks using banking study program students as research objects. By using multiple linear regression analysis, it shows that the variables of knowledge, reputation, environment, and religiosity can explain the variable interest in saving by $51.9 \%$. The results of the analysis show that the Reputation variable and the Religiosity variable have a significance of 0.019 and 0.000 , which means that the variables of reputation and religiosity have a significant effect on students' interest in 
saving in Islamic banks. The results of these findings can provide opportunities for Islamic banks to increase socialization to Muslim communities who do not know about Islamic banks, one of which is by supporting Islamic activities such as recitation, majelis taklim and educating ustadz about Islamic banks in order to help socialize and campaign for the movement of saving in Islamic banks..

Ramadhani, Susyanti, \& ABS (2019) analyze the influence of the level of religiosity, knowledge and social environment on interest in saving Banyuwangi students. The sampling technique used was simple random sampling technique. This research is a quantitative study and the method of data analysis uses multiple linear regression. The results of this study indicate that partially the variables of religiosity, knowledge have a significant effect on students 'interest in saving in Islamic banks, while social environment variables have a positive and insignificant effect on students' interest in saving at Islamic banks. Simultaneously the variables of religiosity, knowledge and social environment have a significant effect on students' interest in saving in Islamic banks at a significance level of less than $5 \%$.

Then, several hypotheses used in this study is;

$\mathrm{H}_{1} \quad$ : Religiosity significantly effect saving interest of students for Islamic banking

$\mathrm{H}_{2} \quad$ : Knowledge is able mediate the effect between religiosity and saving interest of students for Islamic banking

\section{METHODS}

The purpose of this study is explanatory that explains the causal relationship between some variable through hypothesis testing. Multiple linear regression analysis is performed with path analysis to support hypothesis testing. The knowledge variable is an intervening variable that will mediate the relationship between the religiosity variable and students' interest in saving. Broadly speaking, religiosity includes three things are believe (aqeedah), norms or law (sharia) and behavior (morals). Religiosity is the level of belief, trust, and piety in a person undergoing religious law which is manifested in various aspects of life including economic aspects (Suwarsi \& Putri Wulandari, 2018). This variable is assumed to be the main variable that motivates students to make decisions about using Islamic banking services, for example saving. On the other hand, the knowledge is in accordance with the definition of consumer knowledge which is stated with everything that is known and understood by consumers about a product being marketed and is inherent and can influence consumer behavior in buying. Therefore through the support of available information can also encourage someone to make a decision including the purchase (Murniati, Juliasari, \& Hanifah, 2020).

The object of study is Accounting students STIE Widya Gama Lumajang with a total of 1080 active students in the academic year 2019/2020. Sampling was carried out using the purposive method aside with the crite ria being (a) active students and (b) taking Islamic economics courses. Then obtained a number of students 36 respondents with a research instrument in the form of a questionnaire containing statements related to the variables used in this study.

\section{RESULTS AND DISCUSSION}

The regression equation model that can be written from these results in the form of a regression equation Unstandardized coefficients is as follows: ${ }^{Y}=9,095+0,2 X$

The results of the equation explain that the coefficient of variable $X$ is equal to showing a unidirectional relationship variable. In general, it explains that every increase of 1 unit variable value will increase the variable value by and vice versa. 
A good regression model must be free from the problem of deviating from classical or basic assumptions. The results of the normality test show that the equation fulfills the normality assumption with a Sig value $0.194(>\alpha=5 \%)$. The same is true for other classical assumption tests.

The results of testing the hypothesis on the regression equation show that there is a significant influence between the variable $\mathrm{X}$ on $\mathrm{Y}$ with a Sig value of $0.000(<\alpha=5 \%)$. So that variable $\mathrm{X}$ significantly effects the dependent variable $\mathrm{Y}$

The determination coefficient on regression equation is 0,307 , that means $30.7 \%$ of students' interest in saving can be explained by the independent variables in this study, while the rest is $69,3 \%$ by other variables not examined here.

Furthermore, to carry out path analysis related to the intervening variables here, the models that can be written from these results are in the form of the Unstandardized coefficients regression equation as follows:

(1) $Z=19,330+0,129 X$

(2) $Y=-9,335+0,078 X+0,953 Z$

From the results of equation (1) it can be explained that the coefficient of variable $X$ shows a unidirectional relationship between the variables. In general, it explains that every increase of a unit independent variable value will increase the dependent variable value by and vice versa. The same thing is obtained from equation (2) where the relationship between variables $\mathrm{X}$ and $\mathrm{Z}$ to $\mathrm{Y}$ is a unidirectional relationship, which generally explains that every increase of 1 (one) variable value and $Z$ will increase the variable value by the coefficient of each variable and vice versa, with assume that other independent variables are fixed.

Normality test show that equations (1) and (2) fulfill the normality assumption with Sig. value is higher than $\alpha(>\alpha=5 \%)$, is 0,200 and 0,088 . Likewise with other classical assumptions, equations (1) and (2) meet the requirements of the classical assumption test in this study. Next is hypothesis testing, is to determine the effect of the independent variables in the regression equation either partially ( $t$ test) or simultaneously (f test). The results of hypothesis testing in equation (1) indicate that there is a significant effect between the variables.

This hypothesis test shows that only the variables $\mathrm{X}$ are not partially significant. This is indicated by the value of Sig. $=0.077>\alpha=5 \%$. In contrast to other independent variables where the $Z$ variable has a Sig. $=0.000<\alpha=5 \%$. Meanwhile, for simultaneous testing, it is obtained sig $(0.000)<\alpha(0.05)$. So that the conclusions obtained from this test, among others;

1. Variable $(\mathrm{X})$ does not affect the dependent variable $(\mathrm{Y})$ significantly

2. Discipline variable $(Z)$ significantly effects the dependent variable $(Y)$

3. Simultaneously, independent variable $X$ and $Z$ significantly effects the dependent variable $(\mathrm{Y})$

Determination coefficient of equation (1) is 0.248 while equation (2) is 0.657 , this means that for equation (1) saving interest can be explained by religiosity in $24,8 \%$ while the rest influenced by other independent variables. Equation (2) explain that $65.7 \%$ of students' interest in saving can be explained by the independent variables in this study, while the rest is $35.3 \%$ influenced by other variables not examined in this study.

Path Analysis 
This analysis is used to test the causal model of the relationship between variables. Through this path analysis will determine which path is most appropriate and short for an independent variable to the dependent variable.

$$
e_{1}=0,8671
$$

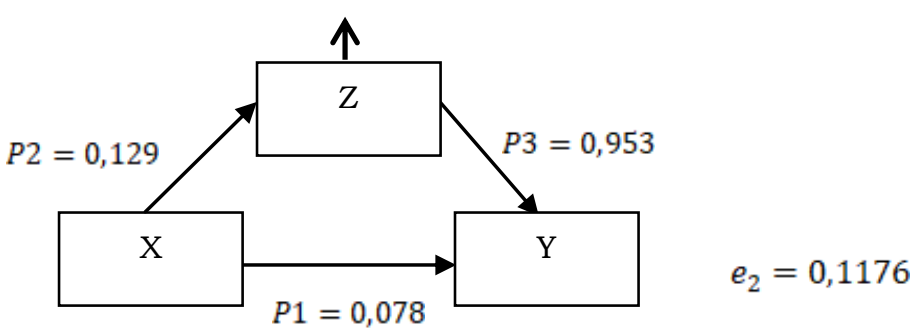

Based on the description of the coefficient, it is known that the direct effect in this study is $\mathrm{p} 1=0.078$, while the indirect effect is obtained by the equation $\mathrm{p} 2 \times \mathrm{p} 3=0.0953 \times$ $0.129=0.122937$. So that the total effect is obtained of 0.200937. Furthermore, the mediation effect shown on the indirect effect can be determined whether significant or not by using the test of Sobel. The result of calculation standard error of $t$ indirect effect coefficient is 0,042471 . Based on this result, the $t$ statistical value $t=\frac{p 2 p 3}{S_{(p 2 p 3)}}=2,894585$

Because the $t$ value of 2.904585 is greater than the $t$ table of 1.645 with a significance of $5 \%$, it is concluded that the mediation coefficient is significant. In other words, there is a mediation effect on this research model.

The results of the hypothesis test above are used as the basis for the discussion of the hypotheses in this study. The first hypothesis states that religiosity significantly effect on saving interest of student. Based on hypothesis testing, the significant value is 0,000 $(<\alpha=5 \%)$ means the hypothesis is accepted.

This is in line with (Rahmawati, 2019), the results of religiosity have a positive and significantly effect on student interest for savings. The same thing happened to research (Lestari, 2015) which states that religiosity has a positive and significant effect. Student religiosity factor is a determining factor in student decisions to save on Islamic banking. The higher the level of student religiosity, greater the tendency for students to save in Islamic banking. On the other hand, the value of religiosity can be used as a basis for making policies in Islamic banking.

The second hypothesis states that religiosity significantly effect on students' interest in saving for Islamic banking with knowledge as an intervening variable. The result of the path analysis states value of $t$ higher than $t$ table for the data study, so it is concluded that the mediation coefficient has a mediating effect. Therefore, the second hypothesis in this study can be accepted. This is in line with research (Rahmawati, 2019) and (Lestari, 2015). The higher the student's religiosity value, the more it will encourage him to seek knowledge related to Islamic banking, both what is prohibited or allowed by religion. In this study, it is proven that the knowledge variable is able to mediate religiosity on the saving interest for Islamic banking.

\section{CONCLUSION}

The results of study that has been conducted by researchers at the Accounting Study Program student of STIE Widya Gama Lumajang through a questionnaire totaling 36 
respondents, is the religiosity variable significantly effect on the saving interest for Islamic banking, and knowledge is able to mediate religiosity towards saving interest student for Islamic banking.

\section{REFERENCES}

Direktorat Perbankan Syariah. (2011). Outlook Perbankan Syariah Indonesia. Bank Indonesia.

Fajar Mujaddid, P. T. A. N. (2019). Pengaruh pengetahuan, reputasi, lingkungan dan religiusitas terhadap minat pelajar Sekolah Menengah Kejuruan prodi perbankan Syariah dalam menabung di bank Syariah. Jurnal Ekonomi Islam, 10(1), 14-37.

Murniati, W. (2018). Penambahan Jumlah Investasi pada Simulasi Perhitungan Profit Model Investasi Syariah Musyarakah. MUST: Journal of Mathematics Education, Science and Technology. https://doi.org/10.30651/must.v3i2.2229

Murniati, W., Juliasari, D., \& Hanifah, N. (2020). DETERMINANTS OF INTEREST IN SAVING FOR STUDENTS IN. Assets: Jurnal Akuntansi Dan Pendidikan, 4(2), 89100.

Otoritas Jasa Keuangan. (2016). Booklet Perbankan Indonesia 2016 Edisi 3.

Otoritas Jasa Keuangan. (2018). Roadmap pengembangan keuangan syariah 2017-2019. In Otoritas Jasa Keuangan.

Rahmawati, W. A. D. (2019). Pengaruh Promosi, Religiusitas, Kepercayaan , dan Lokasi Terhadap Minat Masyarakat Menabung di Bank Syariah dengan Pengetahuan Masyarakat sebagai Variabel Intervening (Studi pada Masyarakat Desa Sraten Kab. Semarang). Salatiga: IAIN Salatiga. SKRIPSI.

Ramadhani, N. Ik., Susyanti, J., \& ABS, M. K. (2019). Analisis Pengaruh Tingkat Religiusitas, Pengetahuan dan Lingkungan Sosial Terhadap Minat Menabung Mahasiswa di Bank Syariah Kota Malang. E-Jurnal Riset Manajemen, 79-87. Retrieved from www.fe.unisma.ac.idemail:e.jrm.feunisma@gmail.com

Suwarsi, A. A., \& Putri Wulandari, N. (2018). IDENTIFIKASI POTENSI NASABAH BARU BANK SYARIAH DITINJAU DARI CUSTOMER SWITCHING INTENTION. Jurnal Ekonomi Dan Bisnis Islam (Journal of Islamic Economics and Business). https://doi.org/10.20473/jebis.v3i2.6808 